\title{
Anatomy Accessory Glands Of Male Reproductive Of Javan Pangolin (Manis javanica)
}

\author{
${ }^{1 *}$ Yusrizal Akmal, ${ }^{1}$ Muliairi, ${ }^{2}$ Chairun Nisa', 2 Savitri Novelina \\ ${ }^{1}$ Faculty of Agriculture, Almuslim University, Jln. Al Muslim, Matangglumpangdua (Bireuen), Aceh 24261 \\ 2Departement of Anatomy, Physiology and Pharmacology. Faculty Veterinary Medicine, Bogor \\ Agricultural University \\ *Coorresponding Author: drh.yusrizal.akmal.msi@gmail.com,
}

\begin{abstract}
This study aimed to learn the morphology accessory glands of male reproductive of pangolin by macroanatomy. Male reproductive organs of a pangolin were used in this study. Morphometric observations included measurements of length, diameter/width of the accesoriae gland were analyzed descriptively. Results of microscopic observation showed that the vesicularis glands had a pair laid at the base of the ampulla dexter and sinister that led to the urethra in the form of an enlarged conical with the width at the caudal and protruding toward ventrad, with the average length and thickness is $1.07 \mathrm{~cm}$ and $0.41 \mathrm{~cm}$. There was prostata when the conical structure met both, observed enlargement of the base of the urethra were also prominent in the direction ventrad. The length and thickness of the prostata pangolin was $1.17 \mathrm{~cm}$ and $0.54 \mathrm{~cm}$. In macroanatomy gland bulbourethralis not visible because it was covered by muscles and glands in the radix penis is attached to the anales gland. Accessory gland of the male reproductive pangolin consists vesikularis glands, prostate and bulbourethralis glands (Cowper's) play an important role in the reproduction process that is vesicularis and prostate gland as a producer of seminal plasma, whereas bulbourethralis glands act as a producer of seminal plasma as well as rinse of urethra channel.
\end{abstract}

Keywords: pangolin (M. javanica), accessories gland, vesikularis glands, prostate and bulbourethralis glands

\section{Introduction}

Pangolin is a unique and interesting mammal. The uniqueness among other body surface is covered by scales that hard as reptiles do not have teeth (toothless), the protrude length tongue and roll of the body when threatened (Breen, 2012), as well as having pyloric teeth in the pyloric stomach (Nisa 'et al. 2010). In addition olfactory abilities pangolin better than the vision capabilities (Robinson 2005). The main meal of the pangolin are ants (Ordo Hymenoptera) and termites (Ordo Isoptera) (Lekagul and McNeely 1977). 
Pangolin is one of the animals that have been given special attention by CITES since 1985 . This is because the rampant illegal trade in pangolins, due to increased market demand, especially from China. Most people, especially the Chinese, have the belief that pangolin scales efficacious as an antiseptic, anti-inflammatory and can cure some diseases such as scabies and rheumatism (Nowak 1997), while the heart, intestines and head anteaters used to cure asthma and heart (Akpona et al. 2008). This led to poaching of the animals is increasing, thus allegedly wild population declined drastically. Indonesia has imposed a zero quota for pangolin since 2000 , but since that time the illegal trade continues to increase from year to year. Pangolin overcome the decline in nature, should be anticipated by performing captivity in an attempt to maintain the populations threatened with extinction. Information on the status of wildlife reproductive biology is very important for the implementation of the ex situ conservation activities (Sita and Aunurohi 2013). One aspect of reproductive biology of wild animals is knowledge of the anatomy and physiology of the reproductive organs of both male and female. Male reproductive organs of mammals consists of a pair of testis (plural: testes), ductus epididymidis, ductus deferens, penis and accessory glands.

Accessory glands in males include vesikularis gland, prostate gland and ampulla bulbourethralis (Colville and Bassert 2002). Secreta gland accessories along with secreta of testis and ductus epididymidis, plays an important role in maintaining sperm motility and metabolic activity (Pineda 2003). The existence of accessory glands are species specific. Not all species have four organs such accessories, as well as the morphology of the gland that is also different (Chugtai et al. 2005; Thomson and Marker 2006).

Until now, data on information morphological characteristics of the male pangolin reproductive accessories glands macroscopicly is still very limited. Data obtained from this study is new information in reproductive biology, particularly on the morphological characteristics of the male reproductive accessory glands on pangolin. In addition the information can become the basis of data and information that is important in the effort to support ex situ conservation through captive breeding activity.

\section{Materials and Methods}

This study used the male reproductive accessories glands of pangolin (M. javanica). Microscopic observation made to the in situ position, shape and size of the male reproductive accessories glands of pangolin that vesicularis gland and prostate bulbourethralis gland. Measurement of the length, diameter/width and thickness is done by using a caliper in $\mathrm{cm}$ units. All observations are documented using a digital camera Canon EOS 400D. Results were analyzed descriptively and presented in the form of tables and figures.

\section{Results and Discussion}

Accessory gland consists of vesikularis gland, prostate and bulbourethralis glands (Cowper's) play an important role in the reproductive process. Accessory gland secretions produce seminal plasma with the largest volume (60-90\%) of the total volume of plasma (Aughey and Frye 2001). The growth of the gland and accessory gland secretion activity is influenced by testosterone (Adebayo et al. 2009). Accessory glands are not all there is on any male animals, sometimes one gland is not owned or even owned, but 
not overly developed (Colville and Bassert 2002). Morphometry reproductive organs of male pangolin accessory glands after fixation is presented in Table 1.

Table 1. Morphometry reproductive organs of male pangolin accessory glands

\section{Accessory glands of male pangolin reproductive organs}

\begin{tabular}{llll}
\hline Morphometry & Glandula vesikularis & Prostata & Bulbourethralis* $^{*}$ \\
\hline length $(\mathrm{cm})$ & 1.07 & 1.17 & - \\
Width $(\mathrm{cm})$ & 0.41 & 0.54 & - \\
\hline
\end{tabular}

* Glandula bulbourethralis (tidak tampak secara makroskopis) Bulbourethralis gland (not visible macroscopically)
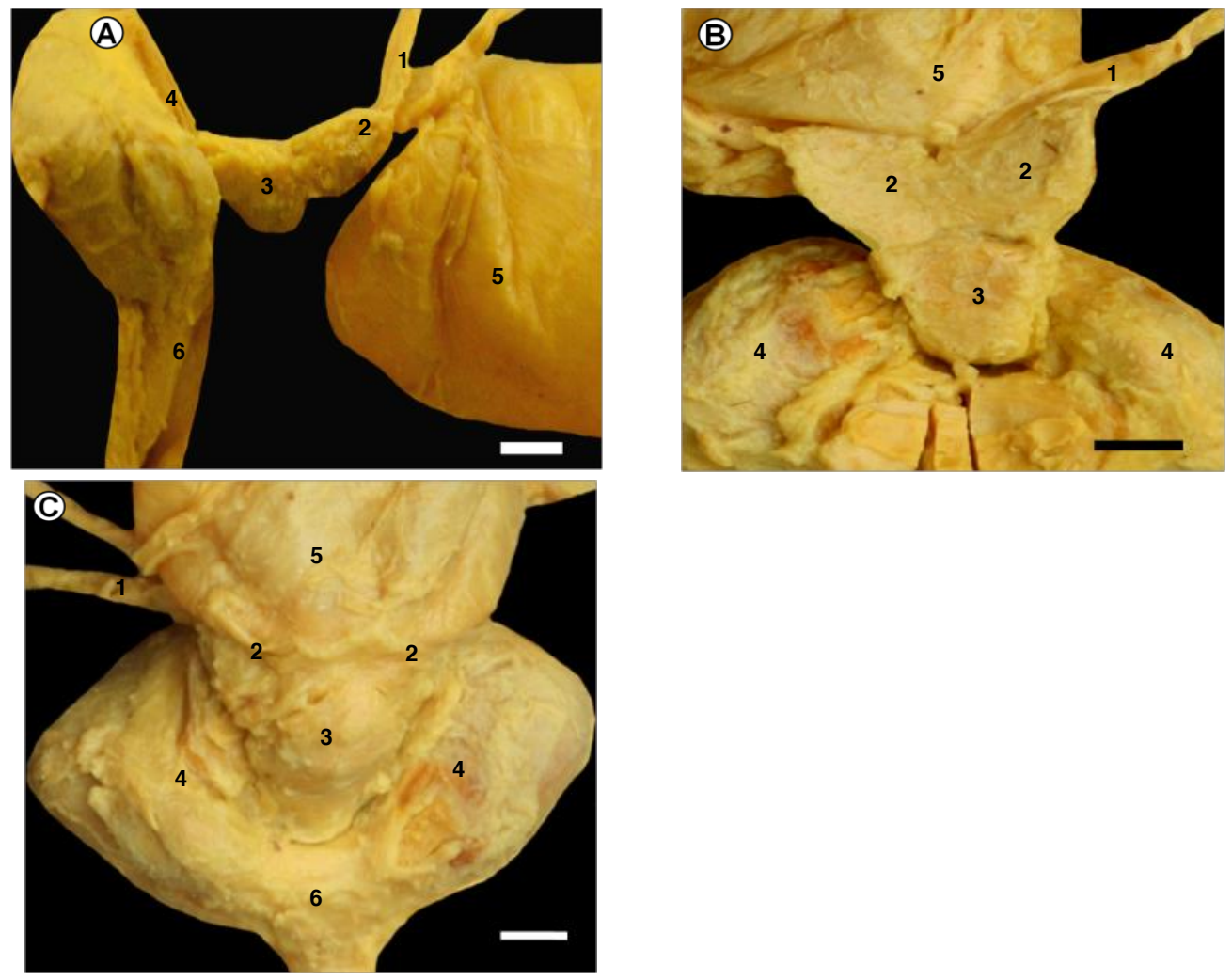

Figure 1. Microanatomy of the male pangolin reproductive accessories glands. lateral (A), dorsal (B) and ventral (C). ductus deferens (1), glandula vesicularis (2), prostata (3), glandulae anales (4), vesica urinaria (5), Penis (6). Bar: $\mathrm{A}-\mathrm{C}=0.5 \mathrm{~cm}$

Vesicularis gland located at the base there is a pair dexter and sinister ampulla which empties into the urethra will be enlarged conical with the wide side in the caudal and protruding toward ventrad (Figure 1). The average length and thickness of the pangolin glands vesicularis is $1.07 \mathrm{~cm}$ and $0.41 \mathrm{~cm}$ (Table 1). 
Vesicularis gland duct enters the urethra in the same area as the ductus deferens. Vesicularis gland found in domestic animals except dogs and cats (Colville and Bassert 2002). The size of sheep vesikularis gland was $0.4 \mathrm{~cm}$ long, $0.2 \mathrm{~cm}$ wide, $0.15 \mathrm{~cm}$ high and weighs $5 \mathrm{~g}$ (Toelihere 1981). On deer, gland vesicularis length of $\pm 1.800 \mathrm{~cm}$ thick and weighs $\pm 0573 \mathrm{~cm} \pm 0.029 \mathrm{~g}$ (Najamudin 2010). The Timor deer vesicularis gland length of $\pm 4,536 \mathrm{~cm}$ (Nalley 2006). Results of this secretions gland containing hexoses, fructose and citric acid with a high concentration which would then be secreted into the seminal coliculus (Hafez 1987). In humans, vesicularis gland plays a role in the formation of seminal plasma coagulation, modification of sperm functions (motility, capacitation) and immunosuppression, as well as reabsorbing liquids or solutes and damaged spermatozoa (Aumüller and Riva 1992). The results of ejaculation using electricity ejaculator show that in the seminal plasma squirrels are granules cartload vesicularis gland in addition to sperm cells (Berdford 1997).

At Pangolin are enlargement of the ductus deferens called ampulla as in most animals, ductus deferens will be enlarged before joining the urethra. Ampulla is an enlargement at the base of the ductus deferens, which is well developed in horses, cattle, sheep, little developed in dogs, but no in pigs. Long ampulla in sheep is $\pm 7.0 \mathrm{~cm}$ (Toelihere 1981), Timor deer $\pm 7253 \mathrm{~cm}$ (Nalley 2006) and deer $\pm 1,733 \mathrm{~cm}$ (Najamudin 2010). Ampulla contains glands which empties into the ductus deferens and helped produce seminal plasma (Frandson et al. 2009). The results of ampulla secretion containing fructose and citric acid, although this more substantia produced by vesicularis glands (Hafez, 1987).

There is prostate contained met in the conical structure both, observed enlargement of the base of the urethra were also prominent in the direction ventrad (Figure 1). The length and thickness of the prostate pangolin is $1.17 \mathrm{~cm}$ and $0.54 \mathrm{~cm}$ (Table 1). Prostate pangolin formed prostate corpus while pars disseminated not found. The prostate is a unpaired gland and surrounds the urethra in the pelvis area. The prostate can be found as corpus prostate and pars disseminated. Corpus prostate is a compact body that is located on the dorsal urethra, while pars disseminated spread inside the walls of the urethra. In dogs and cats, prostate corpus large, globular-shaped and surrounds the entire wall of the urethra (the dog) or most of the walls of the urethra (the cat). Horses only have prostate corpus is large and consists of two lateral lobes connected by isthmus. Cattle and deer Timor has a corpus of disseminated prostate and pars, while the goats and sheep, only had pars disseminated (Getty 1975; King 1993; Nalley 2006). Prostate in deer has a length of $\pm 1,733 \mathrm{~cm}$ thick and weighs $\pm 0.653 \mathrm{~cm} \pm 0.43 \mathrm{~g}$ (Najamudin 2010), while the Timor deer have prostate corpus with a length of $\pm 2.061 \mathrm{~cm}$ (Nalley 2006).

In microanatomy bulbourethralis gland not visible because it was covered by penis radix muscles and glands in the is attached to the anales gland. Bulbourethralis gland known as Cowper's glands, are a pair of glands located in the dorsal urethra of arcus ischiadicus in cranial and caudal glands other accessories. Bulbourethralis gland is found in all animals, except dogs, medium-sized in horses and ruminants, as well as large pigs (Dyce et al. 2002). This gland is covered by a thick capsule that helped shape septum glands and contains many smooth muscle to help remove the secreta. Bulbourethralis gland in sheep length $\pm 0.15 \mathrm{~cm}$, width $\pm 0.1 \mathrm{~cm}$, height $\pm 0.1 \mathrm{~cm}$ and a weight of $\pm 3 \mathrm{~g}$ (Toelihere 1981), while the deer has a length of $\pm 0826 \mathrm{~cm}$, thickness $\pm 0.547 \mathrm{~cm}$ and a weight of $\pm 0.86 \mathrm{~g}$ (Najamudin 
2010 ). Bulbourethralis gland plays a role as a producer of plasma cement and as a rinse urethra channel. Functionally vesicularis glands and prostate play a greater role in the reproductive aspects as seminal plasma source, while the bulbourethralis gland double role as a producer of seminal plasma and as a rinsing urethra channel (Desiani et al. 2000).

\section{Conclusions}

Accessories glands on pangolins consist of a pair of vesicularis gland and prostate gland as well as single bulbourethralis. There are a pair of vesicularis glands located at the base of the ampulla dexter and sinister. There is prostate contained in the conical structure both, observed enlargement of the base of the urethra were also prominent in the direction ventrad. In microanatomy bulbourethralis gland not visible because it was covered by penis radix muscles and glands is attached to the anales gland. Pangolin male reproductive accessories gland play an important role in the reproduction process that is vesicularis gland and prostate as a producer of plasma seminal, whereas bulbourethralis glands act as a producer of plasma seminal as well as rinse urethra channel.

\section{Acknowledgements}

Thanks go to the Director General PHKA for the donation specimen provided in addition to the study material and Anatomy Research Laboratory, Departement of Anatomy, Physiology and Pharmacology. Faculty Veterinary Medicine, Bogor Agricultural University.

\section{References}

Adebayo AO, Oke BO, Akinloye AK. (2009). The gross morphometry and histology of the male accessory sex glands in the greater cane rat (Thryonomys swinderianus,Temminck). Journal Veteriner Anatomy. 2 (2): 41-51.

Akpona HA, Chabi AMS, Djagoun, Sinsin B. (2008). Ecology and ethnozoology of the three-cusped pangolin Manis tricuspis (Mammalia, Pholidota) in the Lama forest reserve, Benin. Mammalia. 72: 198-202.doi:10.1515.MAMM.2008.046

Aughey E, Frye FL. (2001). Comparative Veterinary Histology. London: Manson Publish.

Aumüller G, Riva A. (1992). Morphology and functions of the human seminal vesicle. Andrologia. 24(4):183-196.doi:10.1111/j.1439-0272.1992.tb02636.x

Berdford JM. (1997). Unusual nature and possible evolutionary implications of the male vesicular gland secretion in the tree shrew, Tupaia glis. Anat.Rec. 247: 199-205.

Breen, K. (2012). Manis javanica, Animal Diversity Web, Museum of Zoology [Internet]. University of Michigan. [diunduh 10 Mei 2013]; Tersedia pada: http://animaldiversity.ummz.umich.edu.

Chughtai B, Sawas A, O'malley RL, Naik RR, Khan AS, Pentyala S. (2005). A neglected gland: a review of Cowper's gland. International Journal of Andrology 28: 74-77. 
Colville T, Bassert JM. (2002). Clinical Anatomy and Physiology for Veterinary Technicians. St. Louis: Mosby.

Desiani H, Muhamad K, Adyane IKM, Agungpryono S. (2000). Studi morfologi glandula aksesoris kelamin jantan tupai (Tupaia Glis) dengan tinjauan khusus pada sebaran karbohidrat. Media veteriner. $7(4): 6-10$.

Dyce KM, Sack WO, Wensing CJG. (2002). Textbook of Veterinary Anatomy. Ed ke-3. New York: Saunders.

Frandson RD, Wilke WL, Fails AD. (2009). Anatomy and Physiology of Farm Animals. Ed ke-7. lowa: Wiley-Blackwell.

Getty R. (1975). The Anatomy of the Domestic Animals. Philadelphia. W.B Saunders Comapany.

Hafez ESE. (1987). Reproduction in Farm Animals. Ed ke-5. Philadelphia: Lea and Febiger.

Lekagul B dan McNeely JA. (1977). Mammals of Thailand. Association for the Concervation of Wildlife. Bangkok: Sahakarnbhat co.

Najamudin. (2010). Kajian pola reproduksi pada kancil (Tragulus javanicus) dalam Mendukung Pelestariannya [Disertasi]. Bogor: Institut Pertanian Bogor.

Nalley WMM. (2006). Kajian biologi reproduksi dan penerapan teknologi inseminasi buatan pada rusa timor (Cervus timorensis) [disertasi]. Bogor: Institut Pertanian Bogor.

Nisa' C, Agungpriyono S, Kitamura N, Sasaki M, Yamada J, Sigit K. (2010). Morphological features of the stomach of Malayan pangolin, Manis javanica. Anat. Histol. Embryol. 39:432-439. doi: 10.1111/j.1439-0264.2010.01015.x.

Nowak R. (1997). Walker's Mammals of The World. Ed ke6. Baltimore: The Jhons Hopkins University Press.

Pineda MH. (2003). Male Reproductive System. Dalam: Pineda MH, Dooley MP. lowa, editor. McDonald's Veterinary Endocrinology and Reproduction. Iowa: Iowa State Pr.

Robinson PT. (2005). Zoo and Wild Animal Medicine. Ed ke5. Saunders.

Sita V, Aunurohi. (2013). Tingkah laku makan rusa sambar (Cervus unicolor) dalam konservasi ex-situ di Kebun Binatang Surabaya. Journal Sains dan Seni Pomits. 2(1): 2337-3520.

Thomson AA, Marker PC. (2006). Branching morphogenesis in the prostate gland and seminal vesicles. Differentiation 74: 382-392.

Toelihere MR. (1981). Fisiologi Reproduksi pada Ternak. Bandung: Angkasa. 